\title{
'Dentists' and the establishment of the Anglo-American profession in the eighteenth century: part 3. Official recognition
}

IN BRIEF

- Illustrates the progress of dentists towards official recognition in the eighteenth century.

- Notes the ending of the term 'operator for the teeth' in official documents.

- Discusses the earliest signs of the need for a political voice.

\section{Bishop ${ }^{1}$}

This series of papers examines how the Anglo-American dental profession was established in the eighteenth century, examining its need for a name and identity, public recognition and official status. This third paper describes the introduction of the title dentist as the preferred one when used officially and politically.

\section{INTRODUCTION}

In 2005, Stephen Hancocks, in an editorial discussing appropriate names to apply to members of the dental team said; 'They may be just words but they are essential words for, and words essential to, our identity. Until we can agree that identity among ourselves we cannot expect others such as patients, public, media and politicians to either understand our relationship to one another or indeed to respect our collective voice when we choose to, or need to, use it.' ${ }^{1}$

Very quickly, the new dentists had achieved official appointments to serve the most privileged in society, and the most under-privileged. A name on its own is not enough. It must be used by others not in the profession, and this third paper in a series looking at the emergence of dentists and surgeon-dentists in the eighteenth century presents the evidence for the third Hancock's criterion - political identity (politicians [who] understand our relationship to one another [and] respect our collective voice) and other signs of official acceptance for the new description.

TRADE DIRECTORIES, THE MEDICAL REGISTER, COURT APPOINTMENTS: DENTISTS IN PUBLISHED ANNUAL GAZETTES

It is not unexpected that the Trade Directories of the time led the way in presenting the new dentists in a quasi-official way. When

Unit for the History of Dentistry at King's College London Dental Institute

Correspondence to: Malcolm Bishop

Email:malcolmbishop57@btinternet.com

\section{Refereed Paper}

Accepted 18 June 2014

DOI: 10.1038/sj.bdj.2014.1052

${ }^{\circ}$ British Dental Journal 2014; 217: 649-651

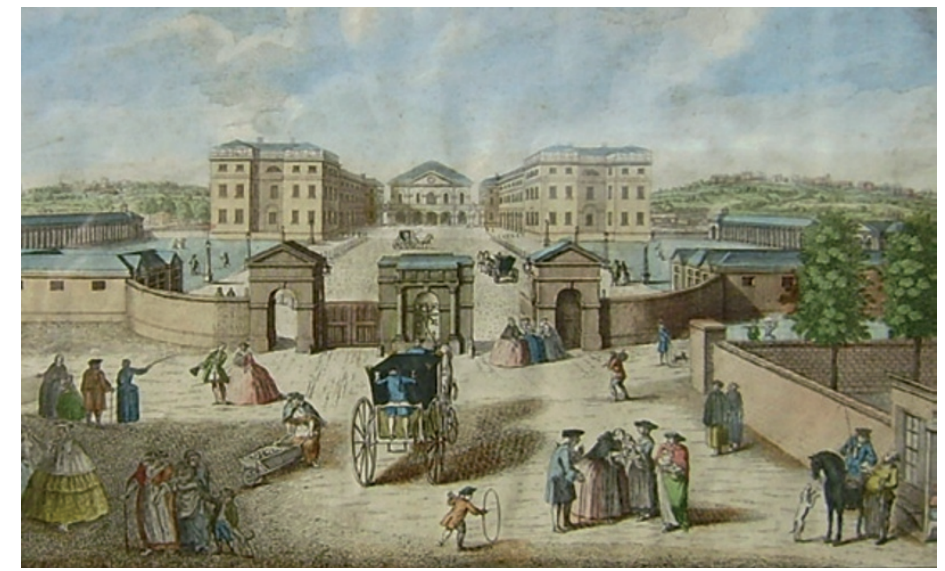

Fig. 1 The Foundling Hospital in 1768.

Private collection

Wright carried out a survey in 1986 of London dentists listed under that description in the Trades Directories in the Guildhall Library, $^{2}$ the earliest use of dentist that he was able to find was by Thomas Berdmore at Racquet Court in Fleet Street in the 1779 edition of Lowndes's Directory. This was some 20 years after the first appearance of the title in England, but the increase in usage after this was rapid, and between then and 1800 , but mostly in the last ten years of the century, nine directories list some 71 dentists or surgeon-dentists (with only one female, but see part two).

Also in 1779 the first edition of the Medical Register was published. ${ }^{3}$ This edition only included four dentists, Messrs. Thomas Berdmore and J Spence as Dentists to his Majesty, and Mr Curtis, Jun. and Mr Rose, both at the Radcliffe Infirmary in Oxford (opened 1770). William Rae is not listed as a dentist, but as a member of the Royal College of Surgeons of Edinburgh (p.50), and as a member of the London Corporation of Surgeons. The important third edition, which was described in detail in part one, ${ }^{4}$ was published in 1783 by a new proprietor. ${ }^{5}$
Considerably enlarged, it now had the separate listing of dentists distinct from the physicians, surgeons, apothecaries, aurists (one) and occulists [sic] (three).

The acceptance of 'dentist' as the generic title in court appointments was somewhat slower than in general usage as there was no particular incentive to change from operator for the teeth. Indeed, it is perhaps surprising that the title of the appointments changed as quickly as it did. The general public did not see the actual court papers, ${ }^{6}$ but there was widespread exposure of the appointments through such publications as the Royal Kalendar, or The Court and City Register Or Gentleman's Complete Annual Kalendar and similar annual gazettes. It was not until 1793 that George Spence was listed as Dentist in Ordinary to the King's (George III (1738-1820)) Household, with T. R. Spence and Thomas Normansell as Dentists Extraordinary. Previously even such well-known dentists as Berdmore and James Spence appeared in the Royal Kalendar under the old terminology as Operators for the Teeth to the King's Household. ${ }^{7}$

However, in 1785 the more modern household of the Prince of Wales (George Augustus 
Frederick, (1762-1830 - given his independent household at the age of 18 in 1780) had appointed Mr Charles Francis Dumergue as dentist, shortly to be joined by the Ruspinis father and son as surgeon-dentists (in 1789). The dentist appointed to the Household of the Duke of York in that year was Mr Fowler.

\section{THE FOUNDLING HOSPITAL, THE RADCLIFFE INFIRMARY, THE LIVERPOOL DISPENSARY: DENTISTS IN PUBLIC SERVICE}

The publication of the appointments of Rae (third edition of the Medical Register) and Parkinson (Royal Kalendar etc. 1797) as dentists to the Foundling Hospital, (Fig. 1) founded in 1741 by Thomas Coram, with Hogarth and Handel among other eminent Governors, is of particular note. Equally important was the appointment of Curtis and Rose at the Radcliffe Infirmary (opened 1770) in Oxford and of the adventurous dental traveller Wooffendale as dentist to The Liverpool Dispensary, (founded 1778). As a philanthropist, Chevalier Bartholomew Ruspini (1727-1813) was particularly known for his founding of the Royal Cumberland Freemasons' School (Royal Masonic Institution for Girls) in 1788.

By these appointments and philanthropic acts, not only did the new title of dentist become more widely disseminated, but the profession was seen to be an integral part of official public health provision.

\section{OBITUARIES AND MEMORIALS, AND PERMANENT LOCATIONS FOR THE LIVING}

The appearance of the professional title in obituaries, memorials, and death notices in the press also brought the new title firmly to the public notice in an official light. The finest example of this is the memorial tablet to Thomas Berdmore (Fig. 2) in 1785 in Nottingham St Mary. ${ }^{8}$ Wider distribution, if less permanent, is found in the death notice directly under the heading 'Obituary of considerable persons; with biographical anecdotes' in August 1790 for 'Mr Jacob Hemet, dentist to her Majesty, New Bond Street' (in an apoplectic fit). This was in The Gentleman's Magazine ${ }^{9}$ in the same edition as the 'notice' of Spence's book on the transmission of disease in transplanting, (see part 2).

In addition to these were notices in the press of the taking over of practices by the legitimate heirs, and notices warning against others flying false colours.

Marmoreal inscriptions for the living were understood to make a statement of professional probity and permanence. Hargreaves reproduces the press announcement of $\mathrm{Mr}$ Safford of Bristol, who in 1798 listed his accomplishments as a surgeon-dentist etc. concluding; "He thinks the advantages that must naturally arise in those who shall please to consult him in preference to itinerant dentists, are too obvious to need mentioning, as he may always be applied to on any emergency, and the strictest secrecy be depended on. N.B. The Name cut in Marble on each Door'. ${ }^{10}$

\section{THE BARBERS AND GAZETTES CATCH UP}

It was not until 1784, just too late for the 1783 Register, that Joseph Fox (1733-1795, and father of the Joseph Fox who lectured on dentistry at Guys from 1799) moved from 'B' for Barber to 'B/Dentist' in the Quarterage Register of the Barbers' Company. (Fig. 3) This however, although in essence permitting those who had served apprenticeships as dentists to become Freemen of the Company, did not prove to be a signal for the new dentists to regard the Barber's company as once more 'their' guild, and dentist registrations thereafter are few and far between.

The change in gazette listings was equally slow, but by 1799 the Royal Kalendar listed only dentists or surgeon-dentists, three in the King's Household, one in the Queen's, three in the Prince of Wales' (and Mr Parkinson at the Foundling Hospital). The operator for the teeth was extinct as an official appointment by the end of the century.

\section{POLITICAL VOICES}

The third Hancock's criterion, the deployment of a collective voice when addressing political action, featured largely, when profession-driven, in the nineteenth century. The reformers and historians Tomes and Hill, who were reluctant to extend recognition to any but a very few of those who called themselves dentists, would not have had much to complain about had the title dentist stayed with the elite of the new profession. But naturally, and rapidly, by the 1790 s, all manner of practitioners gave themselves the name 'dentist' , combining their dental activities with hairdressing, acting, corncutting (Hargreaves et al. give a fascinating variety, ${ }^{11}$ the important sub-group of chemist dentists did not emerge until the nineteenth century), and this can also be seen as a further essential step in the progress of the profession, since the nineteenth century reformers now had a political name which they could use when they came to define what was, and what was not, dentistry, and who by qualification and by law could call themselves dentists.

The first stirrings of the request for political action to control the new dentists did not, however come from the profession. In

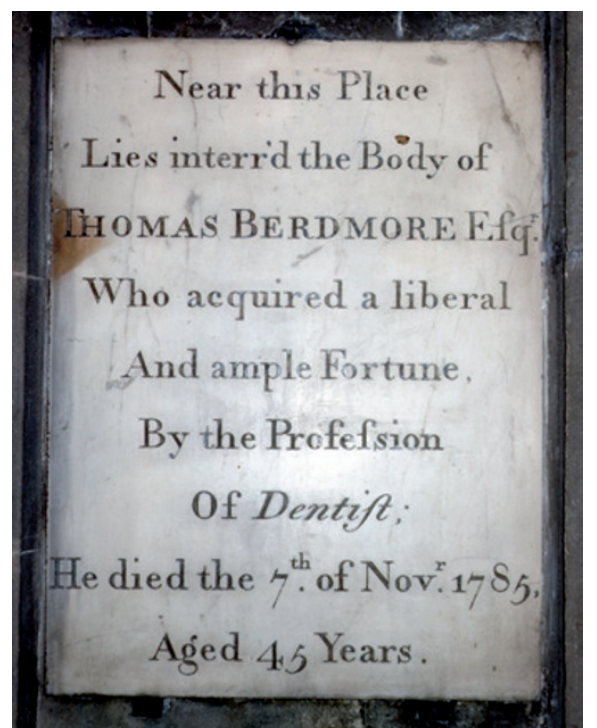

Fig. 2 Berdmore Memorial. Photograph courtesy of Revd. David Harper, Southwell and Nottingham Church History Project

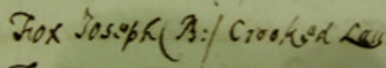

Fig. 3a Joseph Fox, 1783

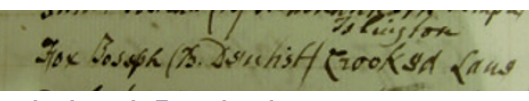

Fig. 3b Joseph Fox, dentist 1784

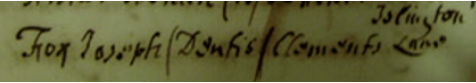

Fig. 3c Joseph Fox, dentist 1785. By kind permission The Honourable Company of Barbers of London

Ireland, where the Surgeons and Barbers did not split, a rueful appeal from Dublin was printed in the 1783 Register; ${ }^{12}$ 'As there is no distinct corporation of surgeons, any man who chooses may follow the profession. Dublin is crowded with irregulars of every species, as dentists, oculists, and menmidwives. It may easily be conceived what injury the public must sustain from such a host of irregulars'.

\section{PROFESSIONAL POLITICS AND THE SURGEONS}

In England, formal relations with the surgeons were not to be established until the nineteenth century, when the endeavours of John Tomes and others succeeded with the introduction of the LDS examination. ${ }^{13}$ However, an important first step may be considered to have been taken by the surgeon and anatomist John Hunter FRS (1728-1793) in 1778 when in the second part of his great work on dental anatomy and dentistry, A Practical Treatise on the diseases of the teeth..., ${ }^{14}$, he made clear the relative functions of the dentist and the surgeon. 'All the diseases of the teeth, which 
are common to them with the other parts of the body, should be put under the management of the physician or surgeon; but those which are peculiar to the teeth and their connections, belong properly to the dentist.' His biographer Jessé Foot, another surgeon, isolated this passage in 1794 in his introduction to the description of Hunter's treatise $^{15}$, where he discusses the merits or otherwise of Hunter's association with dentists, and the elder Spence in particular. The need for a clear political voice when establishing the position of the new professionals in the medical hierarchy was thus already apparent, and from Hunter onwards it was as dentists that these specialists would be known to the surgeons.

\section{SUMMARY}

In the nineteenth century, the practical application of the third component of Hancocks' statement, the deployment of a collective voice when addressing political action, depended entirely on the establishment and acceptance of the professional title of dentist (or surgeon-dentist) in the eighteenth century. In the nineteenth century, as described by Hill ${ }^{16}$ and commented on by Gelbier, ${ }^{17}$ effective collective action under the name of dentist took effect, both in England and America, to give the profession a legal qualification.
In England the culmination of the features identified by Hancocks as being allimportant in the naming of the vocation - self-identity, public acknowledgement, and political existence, came when the profession was given legal and exclusive status by the 1921 Act which stated that; 'For the purposes of this Act, the practice of dentistry shall be deemed to include the performance of any such operation and the giving of any such treatment, advice, or attendance as is usually performed or given by dentists. ${ }^{18}$

In establishing that the dentist is what the dentist does, Hancocks' statement that 'they may be just words but they are essential words for, and words essential to, our identity' was fulfilled.

The fourth part of this series of essays describing the introduction of the title dentist to the profession looks at the spread to North America.

1. Hancocks S. What's in a name? Br Dent J 2005; 199: 65.

2. Wright $\mathrm{D}$ W. London Dentists in the 18th century: a Listing from the trades Directories in the Guildhall Library. Lindsay Club Newsletter. 1986; 12: 8-16.

3. The Medical Register for the Year 1779. London: J. Murray, 1779 .

4. Bishop M G H. 'Dentists' and the establishment of the Anglo-American dental profession in the eighteenth century: part 1 . The need for a name and an identity. Dentists in the Medical Register of 1783. Br Dent J 2014; 217: 537-540

5. The Medical Register for the Year 1783. London: Joseph Johnson, 1783.
6. The Royal Household Index. Royal Household Staff 1526-1924. Available online at http://www. findmypast.co.uk/articles/world-records/search-alluk-records/special-collections/the-royal-archivescollection/royal-household-staff-1526-1924 (accessed 26 November 2014).

7. Berdmore T. A Treatise on the Disorders and Deformities of the Teeth and Gums. London: Printed for the author, 1768.

8. Monuments and Memorials. Nottingham St Mary. Available online at http://southwellchurches.nottingham.ac.uk/nottingham-st-mary/hmonumnt.php (accessed 26 November 2014).

9. The Gentleman's Magazine and Historical Chronicle for the year 1790. Vol 60, part 2. p 770.

10. Hargreaves A. Dentistry in the British Isles. In Hillam C (ed) Dental practice in Europe at the end of the 18th century. p 179. Farley's Bristol Journal 1 September 1798. Clio Medica 72 in The Wellcome Series in the History of Medicine. Amsterdam - New York: Rodopi, 2003.

11. Hargreaves A. Dentistry in the British Isles. In Hillam C (ed) Dental practice in Europe at the end of the 18th century. Clio Medica 72 in The Wellcome Series in the History of Medicine. Amsterdam - New York: Rodopi, 2003

12. The Medical Register for the Year 1783. p 165. London: Joseph Johnson, 1783.

13. Bishop M, Parker M. Sir John Tomes FRS, Fellows of the Royal Society, and dental reform in the 19th century. Notes Rec $R$ Soc Lond 2010; 64: 401-416.

14. Hunter J. A practical treatise on the diseases of the teeth; intended as a supplement to the natural history of those parts. London: J. Johnson, 1778.

15. Foot J. The life of John Hunter. p 128. London: T. Becket, 1794.

16. Hill A. The history of the reform movement in the dental profession during the last twenty years. London: Trübner, 1877.

17. Gelbier S. The Royal Colleges, the LDS and the struggles of the dental profession. Br Dent J 2012; 213: 237-241.

18. Dentists Act, 1921 [11 \& 12 GEO. 5 CH. 21.] An act to amend the Dentists Act, 1878, and the provisions of the Medical Act, 1886, amending that Act. 28 July 1921. 